Fisheries

\title{
Prediction of on-site depuration of paralytic shellfish poisoning toxins accumulated in the scallop Patinopecten yessoensis of Ofunato Bay, Japan
}

\author{
Shinnosuke Kaga ${ }^{1} \cdot$ Shigeru Sato $^{2} \cdot$ Yoshimasa Kaga $^{1} \cdot$ Kimiaki Naiki $^{1} \cdot$ \\ Shiho Watanabe ${ }^{1} \cdot$ Yuichiro Yamada $^{2}$. Takehiko Ogata ${ }^{2}$
}

Received: 25 January 2015 / Accepted: 2 May 2015 / Published online: 22 May 2015

(C) The Author(s) 2015. This article is published with open access at Springerlink.com

\begin{abstract}
In this paper, we present a decay equation for paralytic shellfish poisoning (PSP) toxins using long-term field data spanning more than 10 years in order to predict the detoxification period for the scallop Patinopecten yessoensis in Ofunato Bay, Japan. From the data, we obtained the date of maximum toxicity in the digestive gland (DG) of the scallop and then the date of detoxification. Next, we performed linear regression analysis between $\log _{\mathrm{e}}$ toxicities and days after the maximum toxicity level for each study year. Toxicity declined at a rate of $1.5 \% /$ day, and a period of 3-9 months was required for the scallop to achieve a toxicity level of 20 mouse units (MU)/g DG tissue, which is a critical level for determining monitoring frequency and area of scallop toxicity. We then estimated the number of days needed to reach $20 \mathrm{MU} / \mathrm{g}$ DG tissue $\left(t_{20}\right)$ using the equations obtained by the above-mentioned analysis, and we performed another linear regression analysis between the $\log _{\mathrm{e}}$ (maximum toxicity) and $t_{20}$ for each year. The difference between the actual and predicted detoxification time ranged from -16 to 18 days. We conclude that these equations can be used to predict the depuration of PSP toxins from scallops in Ofunato Bay.
\end{abstract}

Keywords Detoxification rate equation - Dinoflagellate · Scallop detoxification $\cdot$ Paralytic shellfish poisoning

Shinnosuke Kaga

s-kaga@pref.iwate.jp

1 Iwate Fisheries Technology Center, Kamaishi, Iwate 026-0001, Japan

2 School of Marine Biosciences, Kitasato University, Sagamihara, Kanagawa 252-0373, Japan

\section{Introduction}

Bivalves exposed to blooms producing paralytic shellfish poisoning (PSP) toxins vary markedly in their ability to detoxify these accumulated toxins [1]. A field survey along the Pacific coast of northern Japan revealed that Yesso giant scallops Patinopecten yessoensis retained high levels of PSP toxins for a longer duration than the ascidians Halocynthia roretzi, blue mussels Mytilus galloprovincialis, or Pacific oysters Crassostrea gigas [2]. Scallop toxicity and the abundance of toxic dinoflagellates have been monitored in Ofunato Bay, Iwate Prefecture [3-7], since the occurrence of shellfish poisoning in 1961. While studies have shown accumulated PSP toxins in $P$. yessoensis through ingestion of toxic Alexandrium tamarense and Alexandrium catenella $[4,8,9]$, our previous study showed little depletion of the high levels of these toxins in the scallop [4]. After the Great East Japan Earthquake in 2011, accumulation of PSP toxins through the ingestion of A. tamarense was reported in the mussel $M$. galloprovincialis, the scallop P. yessoensis, and other species in Ofunato Bay [10, 11]; in 2013, a study found that a period of 9 months was needed for PSP toxin levels in the scallops to decrease from the maximum to $20 \mathrm{MU} / \mathrm{g}$ digestive gland (DG) tissue [11]. In light of these issues, scallop farming is being replaced by oyster farming, owing to the lower toxicity levels and higher detoxification rates in oysters. In fact, in 2013, the production volume and production value of scallops in Ofunato Bay were 90 tons and 25 million yen, respectively, a reduction of $82 \%$ (407 tons and 113 million yen) compared to those in 2009 [12, 13].

Elucidation of the detoxification kinetics of PSP toxins in the scallop will facilitate prediction of the detoxification period required to reach a level of $20 \mathrm{MU} / \mathrm{g}$ DG tissue and subsequent cost mitigation measures for scallop 
Fig. 1 Map showing the sampling station (St. S) in Ofunato Bay, Iwate Prefecture, Japan

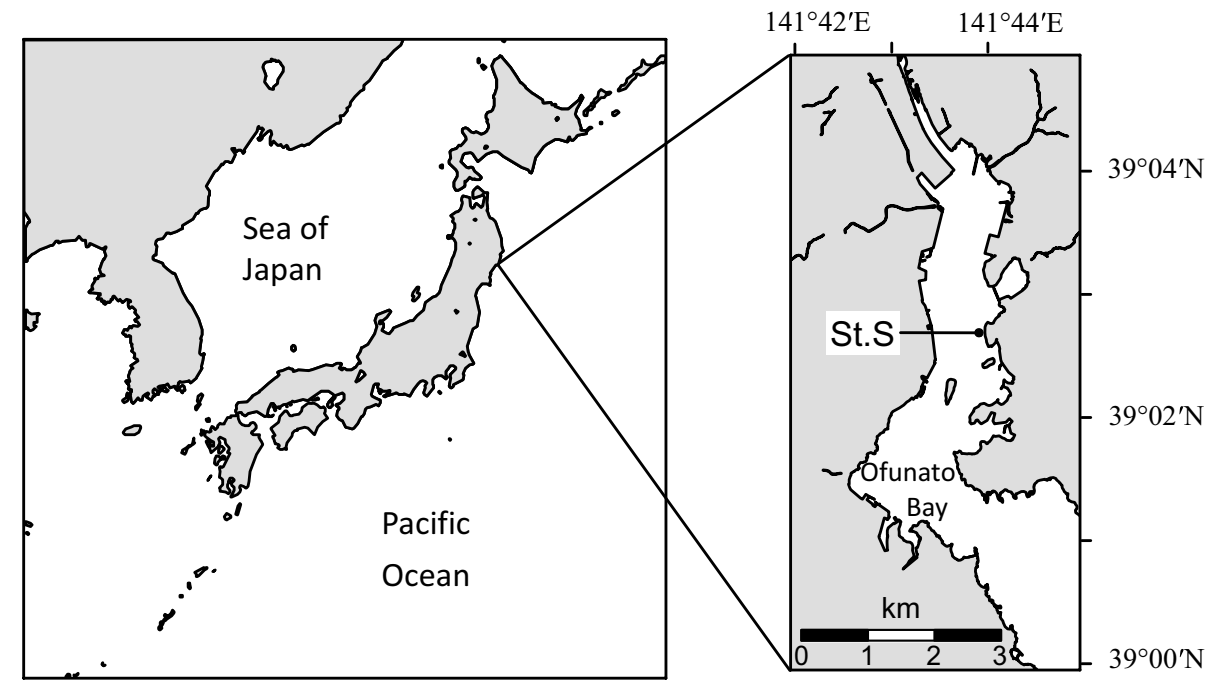

farming. The production of scallops is more intensive than that of other bivalves in Japan, and determination of detoxification rates for scallops would be useful for local fishery cooperatives and fishermen. This information would allow them to calculate the length of closures of areas contaminated with PSP toxins. People engaged in scallop farming could then negotiate with their customers regarding shipment quantities after detoxification and would be able to achieve stable income by planning annual production levels.

It is well known that there are significant differences in detoxification rates among shellfish species [14], which may be affected by interspecific differences in detoxification capacity, such as metabolism (e.g., excretion) of toxins [1]. The rate of detoxification (percentage loss of toxins per day) has been calculated by fitting a negative exponential function of bivalve toxicity levels against time from data derived from laboratory or field studies [1]. Bricelj and Shumway [1] determined a detoxification rate of 1-4 \%/ day in the scallop $P$. yessoensis affected by the dinoflagellate A. tamarense in a field survey on the basis of Japanese reports $[2,4,15,16]$.

Toxins in the scallops accumulated by the ingestion of A. tamarense in feeding experiments likely undergo metabolic processes into derivatives that are undetectable by high-performance liquid chromatography (HPLC). For example, during a no-feeding period in a feeding experiment, some of the toxin supplied (the sum of the amount of toxins in the scallop and that released into the environmental water) seemed to disappear, and most of the supplied toxin was recovered thereafter [17]. This result indicates that decomposition of toxins in the scallop is unlikely, and suggests that the decrease in accumulated toxins is due to excretion of the toxins into the ambient seawater. It is probably for this reason that, to the best of our knowledge, no study has yet determined the detoxification rate of PSP toxins in scallops after ingestion of $A$. tamarense in the field.

In this work, we performed linear regression analysis between the $\log _{\mathrm{e}}$-toxicities and number days after maximum toxic level in the scallop P. yessoensis in order to predict the duration of detoxification using long-term field data (1978-1988) for PSP toxins in Ofunato Bay. Our findings suggest that the equation obtained by the above-mentioned linear regression line is useful to predict the duration of scallop detoxification reaching under the waring level in Ofunato Bay.

\section{Materials and methods}

\section{Sample collection and toxicity assay}

A sampling station (23 m depth) was installed at the Shizu station $\left(39.04^{\circ} \mathrm{N}, 141.73^{\circ} \mathrm{E}\right)$ in Ofunato Bay from May 1978 through December 1988 (Fig. 1). Water samples were collected one to four times per month at depth intervals of $2 \mathrm{~m}$ from the surface to the bottom (12 layers) for monitoring cell numbers of Alexandrium spp. A 500-ml sample of seawater was concentrated by gravity filtration using an $8-\mu \mathrm{m}$ membrane filter (Millipore, type SC; EMD Millipore, Darmstadt, Germany). The concentrate was collected in aliquots of 20 or $40 \mathrm{ml}$, and each 1-ml portion was used for microscopic counting of Alexandrium spp. The Alexandrium spp. observed during the survey were identified as A. tamarense and A. catenella [4-6,8]. Previous research found that the toxicity of $A$. catenella cells collected from Ofunato Bay as detected by mouse assay was significantly 


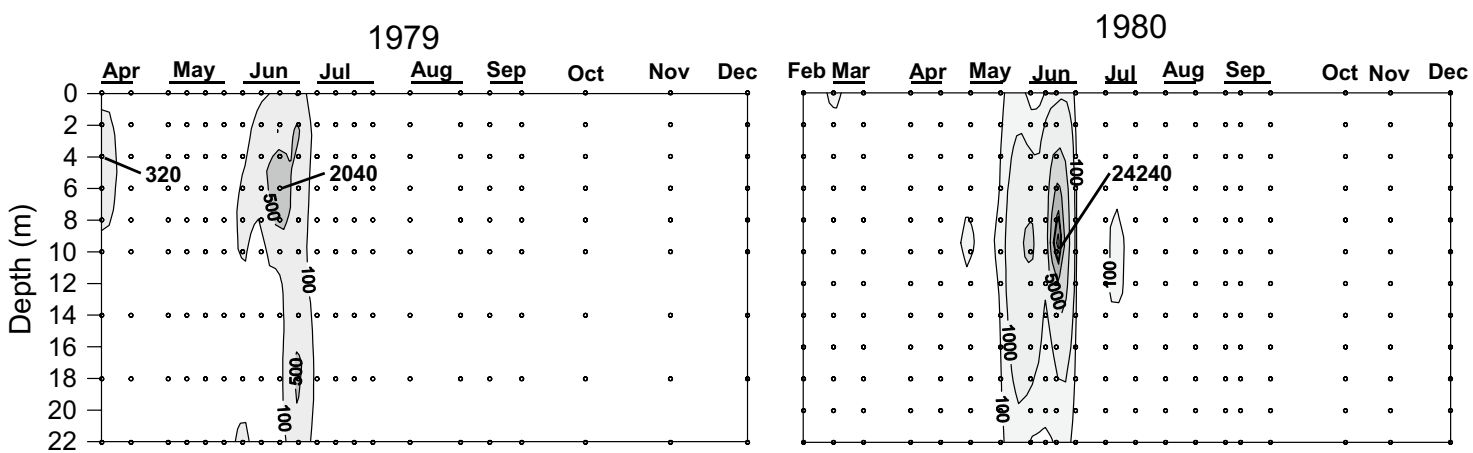

1981

1982

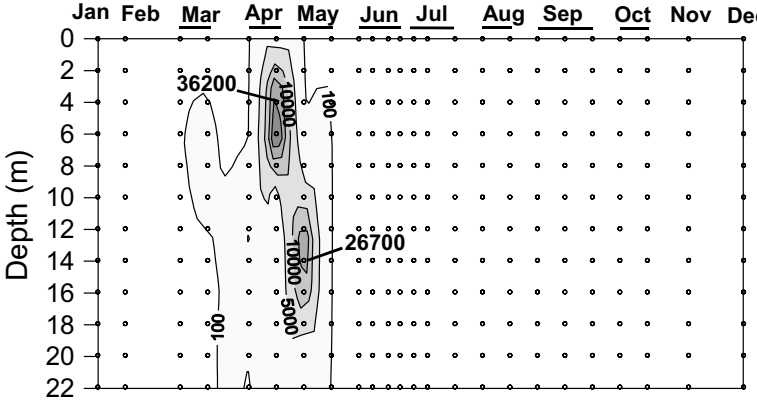

1983

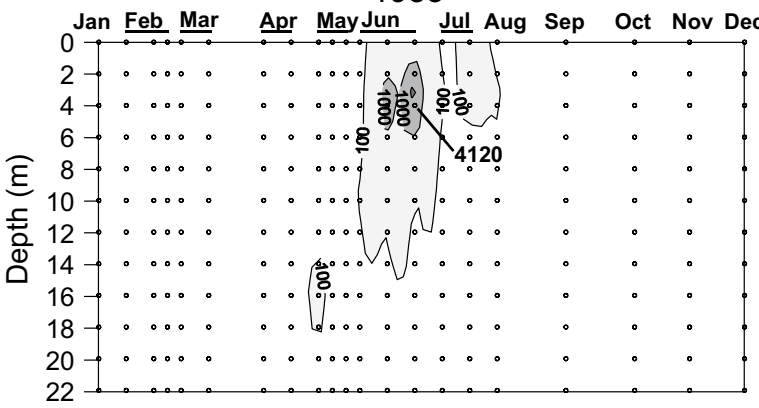

1985

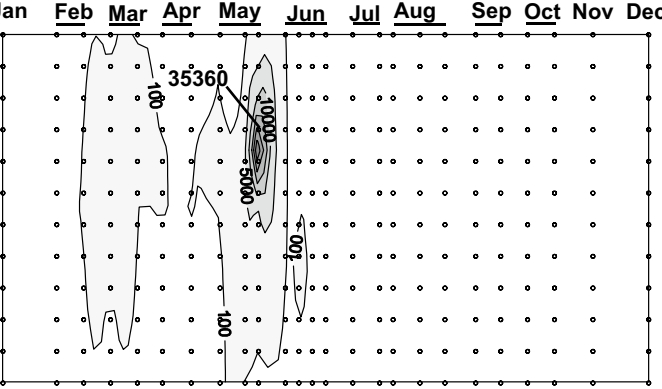

1984

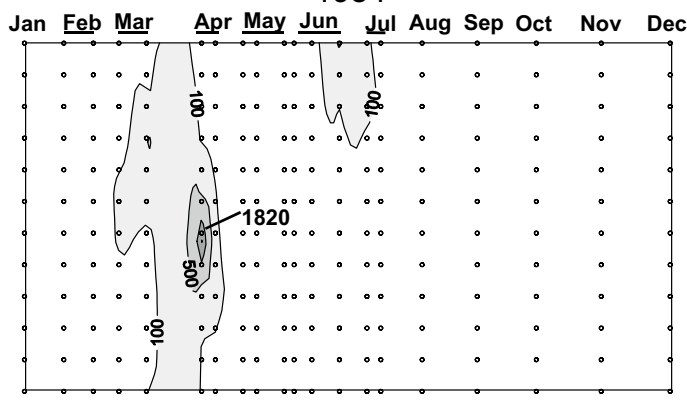

1986

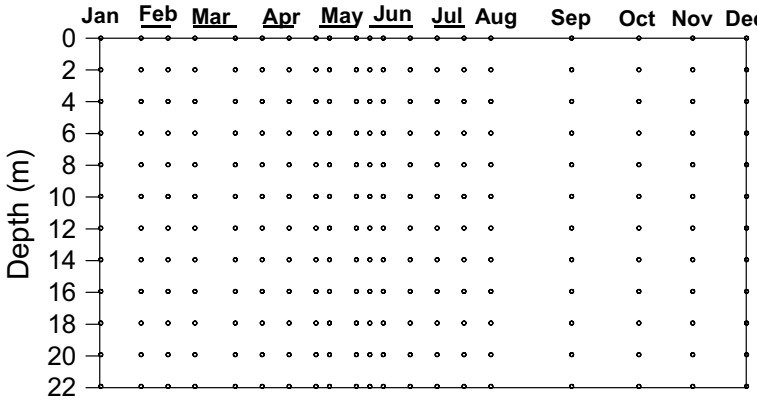

1987

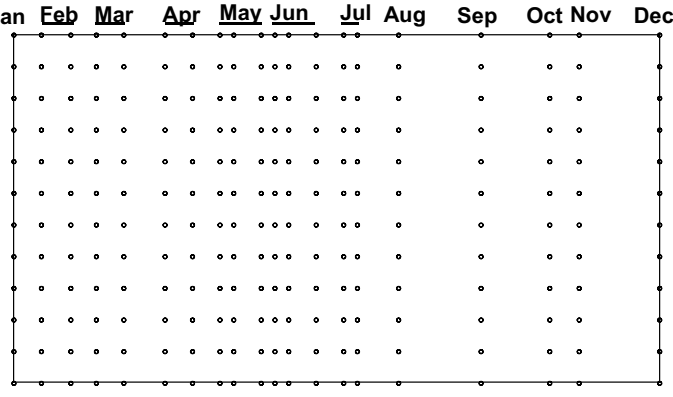

1988

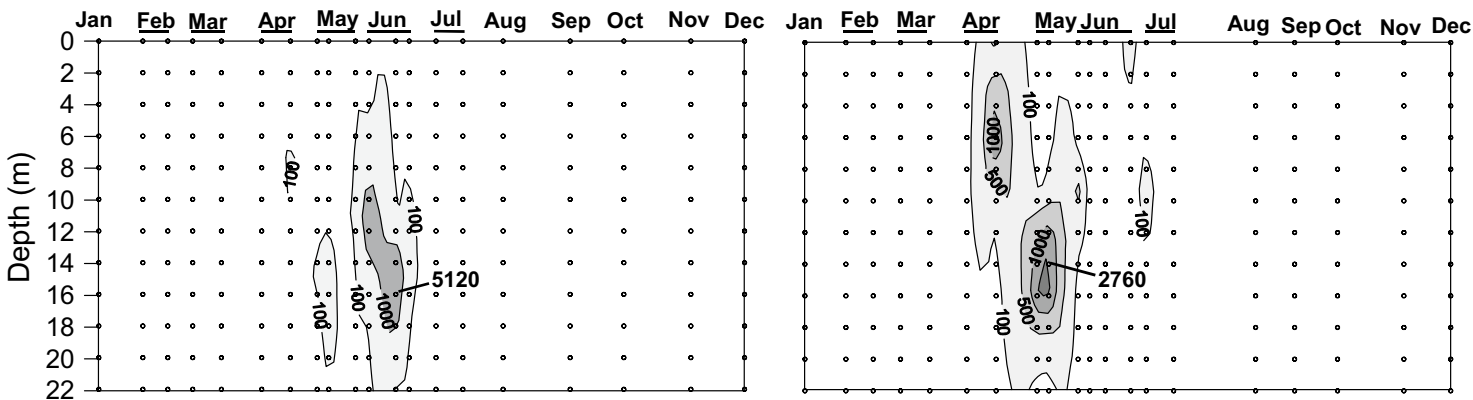

Fig. 2 Temporal change in vertical distribution of Alexandrium tamarense at St. S from 1979 to 1988 . Cell numbers of A. tamarense indicate $\geq 100$ cells/l 

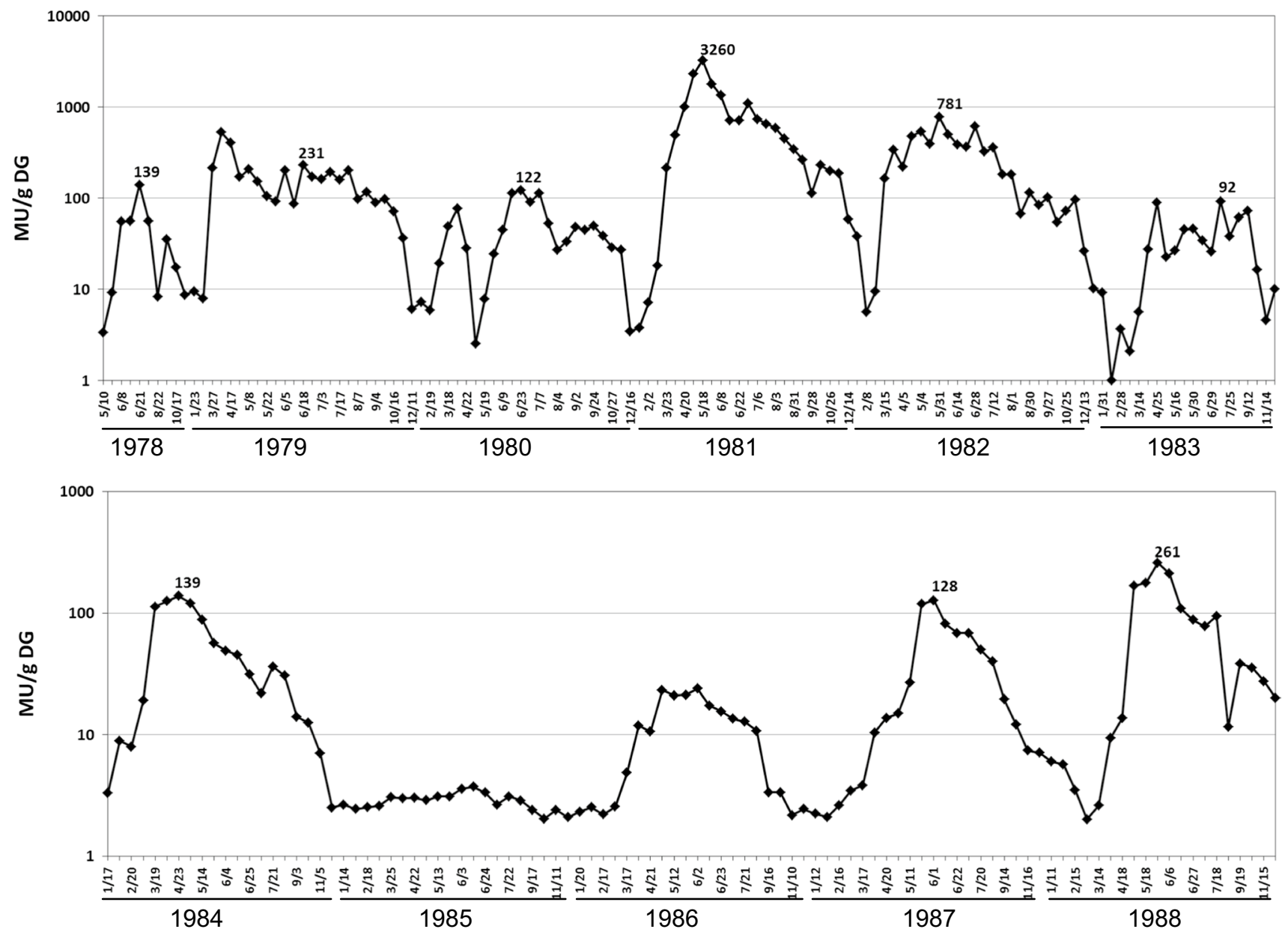

Fig. 3 Toxicity of digestive gland (DG) tissue in terms of mouse unit (MU)/g DG wet tissue weight in the scallop P. yessoensis. Maximum toxicity levels are shown for each year (in 1979, the final peak was adopted as the maximum)

lower $\left(<0.005 \mathrm{MU} / 10^{4}\right.$ cells $)$ than that of $A$. tamarense (0.5-2.6 MU/10 $0^{4}$ cells) [8]. In Ofunato Bay, A. catenella has been found to occur at the surface of the water column [4], where no cultured scallops were placed in this study. Therefore, the cell numbers of $A$. tamarense were adopted, although successful monitoring of $A$. tamarense was not possible in 1978 and 1979 (at depths of 12, 16, and $20 \mathrm{~m}$ ). The nontoxic scallop specimens were transplanted to the station (at a depth of approximately $10 \mathrm{~m}$ ) from February to March each year where A. tamarense had been reported to be most dense $[4,5]$.

Five scallop specimens that had been hung at a depth pf approximately $10 \mathrm{~m}$ were collected for toxicity tests within a few days before or after seawater sampling. The digestive glands were excised, combined, and measured for PSP toxins according to the Association of Official Analytical Chemists (AOAC) method at Ofunato Public Health Center (Iwate Prefecture). Field data in which the maximum toxicity during a year was $<50 \mathrm{MU} / \mathrm{g}$ were excluded from data analysis, as this level is too low to trace changes in toxicity.

\section{Data analysis}

The time course of toxicity in each year was traced from the date of maximum toxicity to the date on which the toxicity reached a level below $20 \mathrm{MU} / \mathrm{g}$. Twenty mouse units per gram of DG tissue is the critical level for the Iwate Prefecture monitoring program for PSP. Sampling frequency must be increased when toxicity in scallops exceeds this level [18]. We performed linear regression analysis between $\log _{\mathrm{e}}$-toxicity and estimated days of decline to $20 \mathrm{MU} / \mathrm{g}$ DG tissue from the date showing the maximum toxicity $\left(t_{20}\right)$ on the basis of parametric Pearson's correlation coefficient and non-parametric Spearman's correlation coefficient tests using the Statcel 2 software program (OMS Publishing, Tokyo, Japan). Normality was verified when necessary. 

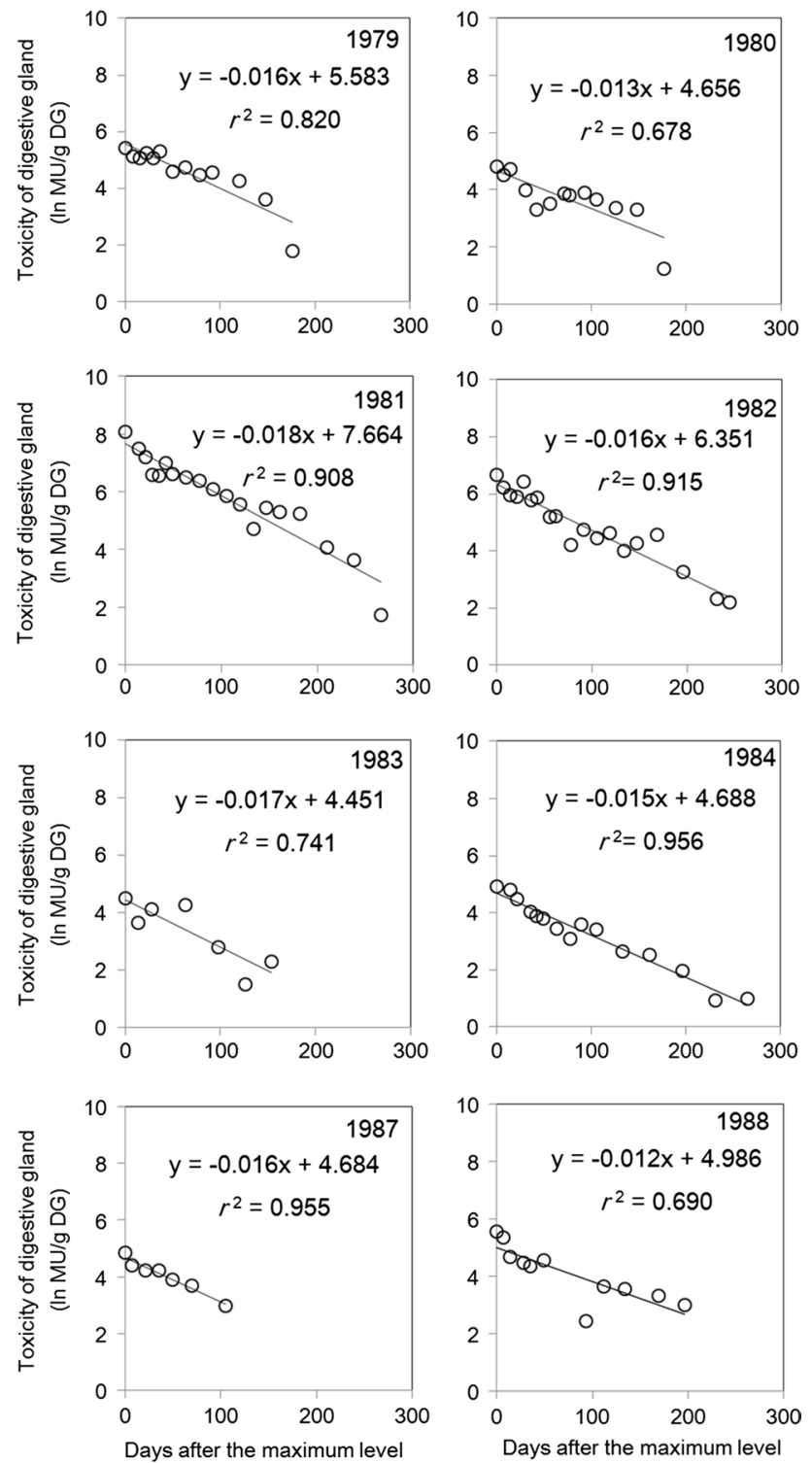

Fig. 4 The relationship between toxicity in digestive gland tissue (MU/g DG wet tissue weight) in the scallop P. yessoensis and number of days in detoxification period after maximum toxic level. Scallops were infected with the dinoflagellate Alexandrium tamarense in Ofunato Bay during eight sampling years. Linear regressions and their coefficients are shown

\section{Results}

\section{Temporal change in vertical distribution of $\boldsymbol{A}$. tamarense}

Figure 2 displays contour graphs showing temporal changes in vertical distribution of $A$. tamarense from 1979 through 1988. Most of A. tamarense were distributed at depths of 4-16 m (excluding 1985 and 1986, when $<100$ cells/l were obtained) (Fig. 2). A. tamarense reached maximum abundance in April through June of each year. The peak bloom was followed by a sharp decrease. The maximum cell number $(36,200$ cells/l) was observed at a depth of $4 \mathrm{~m}$ in April 1981.

When A. tamarense appeared in high densities in Ofunato Bay from 1980 to 1984 (Fig. 2), environmental factors such as water temperature, salinity, concentration of chlorophyll $a$, and inorganic nutrient [nitrate $\left(\mathrm{NO}_{3}{ }^{-}\right)$and phosphate $\left.\left(\mathrm{PO}_{4}{ }^{3-}\right)\right]$ concentrations were within ranges of 5-10 ${ }^{\circ} \mathrm{C}, 33.0-33.7,0.7-8.5 \mu \mathrm{g} / 1,0.3-5.9 \mu \mathrm{M}$, and $0.1-$ $0.7 \mu \mathrm{M}$, respectively [5].

\section{Preparation of the data set}

Maximum toxicity of $P$. yessoensis was observed from April through July each year and ranged from 92 to 3260 MU/g DG tissue (excluding 1985 and 1986, when low toxicity levels were obtained) (Fig. 3). In most years, we observed a rapid decline in toxicity after maximum toxicity was attained (Fig. 3). The average $( \pm S D)$ reduction in toxicity over 1 week was $23.8 \pm 9.1 \%$. In 1979, two toxicity peaks appeared, in May and June, after the first peak (528 MU/g) in April, and we selected June 18 as the date of maximum toxicity (231 MU/g DG tissue) for this year. For the endpoint of the dataset, we selected the date showing a toxicity value $<20 \mathrm{MU} / \mathrm{g}$ DG tissue each year. We obtained 6-19 data pairs for $\log _{\mathrm{e}}$-toxicity and days after the maximum toxic level in each of nine sampling years (1978-1984, 1987, and 1988).

\section{Determination of significance for linear regression lines}

There was a significant reciprocal relationship between $\log _{\mathrm{e}}$-toxicity and number of days in the detoxification period after maximum toxic level in all study years except 1978 ( $P<0.05)$ (Fig. 4; Table 1). Plots were abnormally distributed to some extent in 1979 and 1980, and Spearman's rank test was performed for these data showing significant correlations $(P<0.05)$ (Fig. 4; Table 1$)$. No significant correlation was observed in 1978 (data not shown).

The coefficients obtained were high for all study years. In addition, the detoxification rate was almost constant among all study years (1.5 $\pm 0.2 \%$ /day) (Fig. 4; Table 2). The actual period required for detoxification $\left(t_{20}\right)$ from the date of maximum toxicity varied from 88 to 260 days (Table 3). There was a significant relationship between $t_{20}$ (Fig. 5) and the $\log _{\mathrm{e}}$ (maximum toxicity for each year), and the fitted linear equation was given by:

$y=0.020 x+2.464\left(r^{2}=0.949, P<0.01\right)$

where $y$ is the $\log _{\mathrm{e}}$ (maximum toxicity for each year) and $x$ is detoxification time $\left(t_{20}\right)$. 
Table 1 Relationship between $\log _{\mathrm{e}}$-toxicity and number of days in the detoxification period after maximum toxic level in all study years except 1978
Table 2 Rates of detoxification in digestive gland tissue of the scallop $P$. yessoensis for each study year as determined by linear regression analysis with fitted linear equations
Table 3 Actual and predicted detoxification time indicating number of days required to achieve toxicity level of 20 $\mathrm{MU} / \mathrm{g}$ digestive gland tissue from maximum toxicity for each sampling year

\begin{tabular}{lllll}
\hline Years & $\begin{array}{l}\text { Number of data } \\
\text { pairs }(n)\end{array}$ & $\begin{array}{l}\text { Pearson's correlation } \\
\text { coefficient }(r)\end{array}$ & $\begin{array}{l}\text { Spearman's rank } \\
\text { correlation coefficient }\left(r_{\mathrm{s}}\right)\end{array}$ & Significance $(P)$ \\
\hline 1978 & 6 & -0.790 & - & NS \\
1979 & 13 & - & -0.918 & $*$ \\
1980 & 13 & - & -0.808 & $* *$ \\
1981 & 19 & -0.953 & - & $* * *$ \\
1982 & 19 & -0.957 & - & $* * *$ \\
1983 & 7 & -0.861 & - & $*$ \\
1984 & 15 & -0.978 & - & $* * *$ \\
1987 & 7 & -0.977 & - & $* * *$ \\
1988 & 11 & -0.830 & - & $* *$ \\
\hline
\end{tabular}

NS not significant

$* 0.01 \leq P<0.05$

$* * 0.001 \leq P<0.01$

*** $P<0.001$

\begin{tabular}{lllll}
\hline Years & $a$ & $\begin{array}{l}\text { Coefficient of } \\
\text { determination }\left(r^{2}\right)\end{array}$ & $\begin{array}{l}\text { Significance of } \\
\text { regression coefficient } \\
(P)\end{array}$ \\
\cline { 2 - 4 } Regression coefficient & $\begin{array}{l}\text { Detoxification rate } \\
(\% / \text { day })\end{array}$ & $* * 82$ \\
\hline 1979 & -0.0158 & 1.58 & 0.68 & $* *$ \\
1980 & -0.0133 & 1.33 & 0.91 & $* *$ \\
1981 & -0.0180 & 1.80 & 0.92 & $* *$ \\
1982 & -0.0162 & 1.62 & 0.74 & $* *$ \\
1983 & -0.0165 & 1.65 & 0.96 & $* *$ \\
1984 & -0.0147 & 1.47 & 0.95 & $* *$ \\
1987 & -0.0157 & 1.57 & 0.69 & $* 3$ \\
1988 & -0.0118 & 1.18 & & \\
\hline
\end{tabular}

$* P \leq 0.05$

** $P \leq 0.01$

\begin{tabular}{|c|c|c|c|c|c|}
\hline \multirow[t]{2}{*}{ Years } & \multicolumn{3}{|c|}{ Equation used: $y=a x+b$} & \multirow{2}{*}{$\begin{array}{l}\text { Equation used: } \\
y=0.020 x+2.464 \\
x_{\mathrm{p}} \text { (predicted days) } y=\ln \\
\text { (maximum toxicity) }\end{array}$} & \multirow[t]{2}{*}{$x_{\mathrm{a}}-x_{\mathrm{p}}$ Difference (days) } \\
\hline & $a$ & $b$ & $x_{\mathrm{a}}$ (actual days) $y=\ln (20)$ & & \\
\hline 1979 & -0.0158 & 5.583 & 164 & 146 & 18 \\
\hline 1980 & -0.0133 & 4.656 & 125 & 115 & 10 \\
\hline 1981 & -0.0180 & 7.664 & 260 & 276 & -16 \\
\hline 1982 & -0.0162 & 6.351 & 207 & 206 & 1 \\
\hline 1983 & -0.0165 & 4.451 & 88 & 101 & -13 \\
\hline 1984 & -0.0147 & 4.688 & 115 & 121 & -6 \\
\hline 1987 & -0.0157 & 4.684 & 107 & 117 & -10 \\
\hline 1988 & -0.0118 & 4.986 & 169 & 152 & 17 \\
\hline
\end{tabular}

From this equation, the predicted detoxification time $\left(x_{\mathrm{p}}\right)$ varied from 101 to 276 days (Table 3; Fig. 5). The difference between actual and predicted detoxification duration ranged from -16 to 18 days (Table 3 ).

\section{Discussion}

Retoxification based on the presence of $A$. tamarense after maximum toxicity levels were reached in scallops 


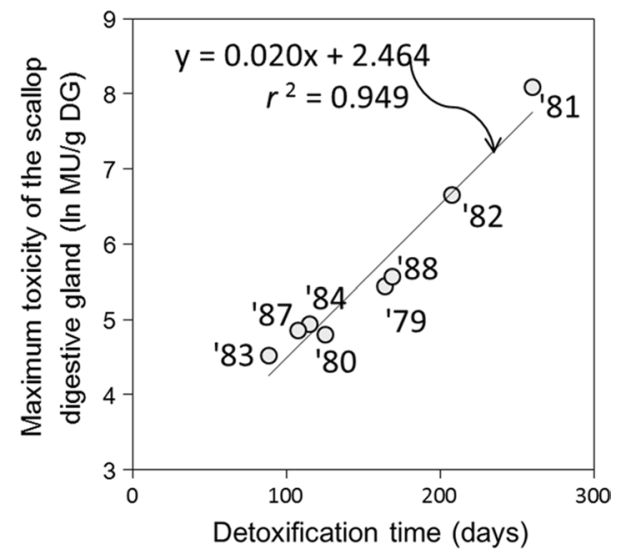

Fig. 5 Relationship between number of days in detoxification period required to achieve $20 \mathrm{MU} / \mathrm{g}$ digestive gland (DG) tissue from maximum toxic level $\left(t_{20}\right)$ and $\log _{\mathrm{e}}$-maximum toxicity for each sampling year. Detoxification periods for the scallop $P$. yessoensis infected with the dinoflagellate Alexandrium tamarense in Ofunato Bay, Japan, from1979 through 1988 (excluding 1985 and 1986) were used

was hardly observed when the abundance of $A$. tamarense decreased to $<100$ cells/l after $2-5$ weeks from the date on which maximum toxicity was observed (Figs. 2, 3).

Bricelj and Shumway [1] reported that a period of 3.75-15 months was necessary for detoxification of $A$. tamarense-contaminated Yesso giant scallops P. yessoensis to levels below the regulatory limit $(0.8 \mu \mathrm{g}$ STXeq or $4 \mathrm{MU} / \mathrm{g}$ DG tissue). In the present study, detoxification of PSP from maximum toxicity levels required approximately 3-9 months (Table 3). In Ofunato Bay, PSP toxin levels of $>2000 \mathrm{MU} / \mathrm{g}$ DG tissue were observed in 1981, 1989, 1993 and 1998 [5, 6, 10]. Using our linear equation, it took approximately 9 months for toxin levels to drop to 20 MU/g DG tissue. This is consistent with our findings that the scallops in Ofunato Bay retained PSP toxin levels over $20 \mathrm{MU} / \mathrm{g}$ DG tissue for 3-9 months.

Our observed rates of detoxification $(1.5 \pm 0.2 \% /$ day; Table 2; Fig. 4) for the scallops are also in agreement with the findings of Bricelj and Shumway [1], who calculated detoxification rates of 1-4 \%/day (DG tissue). However, our rates are lower than those reported for the Pacific oyster C. gigas (38\%/day for DG and $31 \%$ /day for whole tissue) $[19,20]$, the short-necked clam Tapes japonica ( $8 \% /$ day for whole tissue) [21], the blue mussel M. galloprovincialis (M. edulis) (14\%/day for DG and $11 \% /$ day for whole tissues) [1, 22], and the ascidian $H$. roretzi (3\%/day for hepatopancreas tissue) [2]. Thus, the DG of the scallop retains A. tamarense-induced PSP toxins longer than the DG of the oyster and the blue mussel and the hepatopancreas of the ascidian [2]. In feeding experiments with $A$. tamarense, PSP toxicity was retained longer in whole tissues of the king scallop Pecten maximus and the blue mussel than in those of the Pacific oyster or the short-necked clam Ruditapes philippinarum [23]. Oshima et al. [2] suggested that when frequent sampling is not practical, the scallop can provide a good index for predicting past contamination with PSP toxins.

Toxicity levels in the scallop declined rapidly after maximum toxicity was reached (Fig. 3), as observed previously by other researchers $[2,4,22]$. However, the rate of toxicity reduction 1 week after the maximum value $(24 \%)$ was lower in the present study than that observed by Suzuki et al. (47\%) [22]. In addition, maximum toxicity in our study was higher than that observed by Suzuki et al. (70 MU/g DG tissue) [22]. These differences suggest that lower maximum toxicity levels lead to more rapid detoxification. Therefore, linear equations developed using a time-dependent decay of toxicity values should be modified by the maximum toxicity values when estimating detoxification.

In conclusion, the linear regression equation obtained in the present study is useful for predicting the duration of detoxification in scallops in Ofunato Bay. Because the biphasic detoxification model (e.g., initial rapid decline and subsequent exponential decline in toxins) is widely accepted in describing the detoxification kinetic patterns in bivalves, further investigation incorporating this model will be needed to establish a more accurate and reasonable method for predicting detoxification in scallops.

Acknowledgments We would like to thank Dr. S. Watabe for assistance with English corrections and for his valuable comments on an earlier draft of this paper. We also thank Dr. K. Sekiguchi for his useful comments. The authors are grateful to the Iwate Federation of Fisheries Cooperative Associations and the Ofunato Fisheries Cooperative Association for their kind assistance with the field survey. The toxicity of samples was analyzed by the Iwate Prefectural Institute of Public Health. This work was supported in part by the Research Fund for Reconstruction Aid for the East Japan Great Earthquake Disaster, Japanese Society of Fisheries Oceanography PICES/ICES; the Regulatory Research Projects for Food Safety, Animal Health and Plant Protection (no. 2602); and the Tohoku Ecosystem-Associated Marine Sciences (TEAMS) research program of the Ministry of Education, Culture, Sports, Science and Technology (MEXT).

Open Access This article is distributed under the terms of the Creative Commons Attribution 4.0 International License (http://creativecommons.org/licenses/by/4.0/), which permits unrestricted use, distribution, and reproduction in any medium, provided you give appropriate credit to the original author(s) and the source, provide a link to the Creative Commons license, and indicate if changes were made.

\section{References}

1. Bricelj VM, Shumway SE (1998) Paralytic shellfish toxins in bivalve molluscs: occurrence, transfer kinetics, and biotransformation. Rev Fish Sci 6:315-383

2. Oshima Y, Yasumoto T, Kodama M, Ogata T, Fukuyo Y, Matsuura F (1982) Features of paralytic shellfish poison occurring in Tohoku District. Nippon Suisan Gakkaishi 48:525-530 
3. Kawabata T, Yoshida T, Kubota Y (1962) Paralytic shellfish poison-I. A note on the shellfish poisoning occurred in Ofunato City, Iwate Prefecture in May, 1961. Nippon Suisan Gakkaishi 28:344-351

4. Ogata T, Kodama M, Fukuyo Y, Inoue T, Kamiya H, Matsuura F, Sekiguchi K, Watanabe S (1982) The occurrence of Protogonyaulax spp. in Ofunato Bay, in association with the toxification of the scallop Patinopecten yessoensis. Nippon Suisan Gakkaishi 48:563-566

5. Sekiguchi K, Inoguchi N, Shimizu M, Saito S, Watanabe S, Ogata T, Kodama M, Fukuyo Y (1989) Occurrence of Protogonyaulax tamarensis and shellfish toxicity in Ofunato Bay from 1980-1986. In: Okaichi T, Anderson DM, Nemoto T (eds) Red tides: biology, environmental science, and toxicology. Elsevier, New York, pp 399-402

6. Sekiguchi K, Inoguchi N, Kikuchi T, Kaga Y, Sato M, Sato K, Sato S, Ogata T, Kodama M (1996) Comparison of bloom patterns of Alexandrium tamarense between two bays in Iwate Prefecture, northern Japan, in association with the toxicity of the scallop, Patinopecten yessoensis. In: Yasumoto T, Oshima Y, Fukuyo Y (eds) Harmful and toxic algal blooms. Intergovernmental Oceanographic Commission of UNESCO, Paris, pp 223-226

7. Kaga S, Sekiguchi K, Yoshida M, Ogata T (2006) Occurrence and toxin production of Alexandrium spp. (Dinophyceae) in coastal waters of Iwate Prefecture, Japan. Nippon Suisan Gakkaishi 72:1068-1076 (in Japanese with English abstract)

8. Kodama M, Fukuyo Y, Ogata T, Igarashi T, Kamiya H, Matsuura F (1982) Comparison of toxicities of Protogonyaulax cells of various sizes. Nippon Suisan Gakkaishi 48:567-571

9. Sekiguchi K, Ogata T, Kaga S, Yoshida M, Fukuyo Y, Kodama M (2001) Accumulation of paralytic shellfish toxins in the scallop Patinopecten yessoensis caused by the dinoflagellate Alexandrium catenella in Otsuchi Bay, Iwate Prefecture, northern Pacific coast of Japan. Fish Sci 67:1157-1162

10. Kaga S, Watanabe R, Nagai S, Kamiyama T, Suzuki T (2012) Accumulation of paralytic shellfish toxins in bivalves caused by the dinoflagellate Alexandrium tamarense in Ofunato Bay, Iwate Prefecture, northern Pacific coast of Japan after the 2011 Tohoku-Oki earthquake. Gekkan Kaiyo 44:321-327 (in Japanese)

11. Kaga S, Naiki K, Watanabe S (2013) Development of monitoring system on shellfish toxins. Annual reports of Iwate fisheries technology center, Heisei, pp 91-97 (in Japanese)

12. Iwate Prefecture (2012) Fish type production of major shallow sea aquaculture in Iwate Prefecture. Iwate fisheries technology center, annual report 2010 (in Japanese)
13. Iwate Prefecture (2015) Fish type production of major shallow sea aquaculture in Iwate Prefecture. Iwate fisheries technology center, annual report 2013 (in Japanese)

14. Hurst JW, Gilfillan ES (1977) Paralytic shellfish poisoning in Maine. In: Wilt ES (ed) Tenth national shellfish sanitation workshop. United States Department of Health, Education and Welfare, Food and Drug Administration, Washington, pp 152-161

15. Nishihama Y (1980) Seasonal abundance of Protogonyaulax sp. causing paralytic shellfish poisoning in Funka Bay, Hokkaido, Japan, 1978-1980. In: Brenda RM, Richard AN (eds) Proceeding of the North Pacific aquaculture symposium. Anchorage, pp 319-327

16. Tazawa T, Ito T, Ishige M, Sato N (1988) Seasonal variation of paralytic shellfish poison in scallops from Funka Bay. Rep Hokkaido Inst Public Health 38:63-65

17. Sekiguchi K, Sato S, Ogata T, Kaga S, Kodama M (2001) Accumulation and depuration kinetics of paralytic shellfish toxins in the scallop Patinopecten yessoensis fed Alexandrium tamarense. Mar Ecol Prog Ser 220:213-218

18. Yamamoto M, Yamasaki M (1996) Japanese monitoring system on shellfish toxins. In: Yasumoto T, Oshima Y, Fukuyo Y (eds) Harmful and toxic algal blooms. Intergovernmental Oceanographic Commission of UNESCO, Paris, pp 19-22

19. GuŽguen M, Bardouil M, Baron R, Lassus P, Truquet P, Massardier J, Amzil Z (2008) Detoxification of Pacific oyster Crassostrea gigas fed on diets of Skeletonema costatum with and without silt, following PSP contamination by Alexandrium minutum. Aquat Living Resour 21:13-20

20. Yamamoto M, Flynn KJ, Takayama H (2003) Application of a two-compartment one-toxin model to predict the toxin accumulation in Pacific oyster in Hiroshima Bay, Japan. Fish Sci 69:944-950

21. Morisaki S, Mizokoshi T, Yamashita H (2007) Paralytic shellfish poisoning in bivalves collected at the coast of Kamae (20032007). Annu Rep Oita Prefect Inst Health Environ 35:25-46 (in Japanese)

22. Suzuki T, Yamasaki M, Ota H (1998) Comparison of paralytic shellfish toxin profiles between the scallop Patinopecten yessoensis and the mussel Mytilus galloprovincialis. Fish Sci 64:850-851

23. Lassus P, Fremy JM, Ledoux M, Bardouil M, Bohec M (1989) Patterns of experimental contamination by Protogonyaulax tamarensis in some French commercial shellfish. Toxicon 27:1313-1321 